\title{
TYPOLOGICAL STUDY AND CATALOGUING OF LATE MEDIEVAL MANOR HOUSES OF THE BASQUE COUNTRY (SPAIN)
}

\author{
D. Luengas-Carreño ${ }^{1, *}$, M. Crespo de Antonio $^{2}$, S. Sánchez-Beitia ${ }^{3}$ \\ ${ }^{1}$ Department of Architecture, School of Architecture, University of the Basque Country UPV/EHU, Plaza Oñati 2, 20018 Donostia- \\ San Sebastian, Spain - daniel.luengas@ehu.eus \\ ${ }^{2}$ Basque Government Education, Xalbador Bertsolaria 9, 20018 Donostia - San Sebastián (Spain) - maite.crespo@ehu.eus \\ ${ }^{3}$ Department of Applied Physics I, School of Architecture, University of the Basque Country UPV/EHU, Plaza Oñati 2, 20018 \\ Donostia-San Sebastian, Spain - santiago.sanchez@ehu.eus
}

Commission II - WG II/8

KEY WORDS: Manor Houses, Typological study, Late Middle Ages, Basque Country, Vernacular Architecture.

\begin{abstract}
:
Manor Houses were the homes and centres of operation of Basque noble families during the Late Medieval Period. From early defensive Tower Houses to the Palaces of the early 16th century, Manor Houses evolved during the Late Middle Ages, adapting to different historical periods. Despite their heritage value, these buildings are in danger of being lost. Investigations of past centuries encouraged the emergence of false beliefs around Manor Houses - excessively old constructive periods, assignment of defensive origins to most buildings, etc. - . This has resulted in serious errors in heritage catalogues and, subsequently, a high number of unfortunate architectural interventions. This paper aims to analyse and characterize the typological evolution of Basque Manor Houses, in order that the results be used as guideline for future protection strategies. The work was divided into three sections: field work, documentary research and historical-constructive analysis. Collected data was uploaded into QGIS software, which was then used to carry out a comparative analysis. An inventory of 2050 Manor Houses has been developed, which includes a "Red List" of 472 buildings in danger of being lost. Five typologies of Manor Houses have been identified: one with a defensive function - the Tower House - and four types of nondefensive constructions - Tower Palace, Rural Palatial House, Large Palace and Village Manor House-. Most of the existent Basque Manor Houses were built after the mid-15th century and were non-defensive from their original construction.
\end{abstract}

\section{INTRODUCTION}

Late Medieval Manor Houses are one of the most important heritage elements of the Basque Country. In addition to their architectural value, Manor Houses are a reflection of the turbulent society in which they were built. From the first defensive Tower Houses to the pre-renaissance Palaces of the early 16th Century, Manor Houses evolved over the 14th and 15 th centuries. These buildings were the homes and centres of operation for diverse elites that dominated the Basque territories in the Late Middle Ages - the rural nobility, urban oligarchs, wealthy merchants and ecclesiastical elites-, who adapted this type of housing to their specific needs.

Research work carried out during the 16th and 19th centuries contributed to the emergence of false beliefs around Manor Houses, which have endured to the present day. These false beliefs, especially the allocation of excessively old constructive periods and defensive origins to most buildings, have led to the erroneous cataloguing and classification of many of these buildings. This in turn has let to a large number of inappropriate interventions. Additionally, many of the official heritage catalogues and regulations contain errors, such as outdated information, erroneously located areas of archaeological interest and incorrect typological classifications - most of the Manor Houses are registered as defensive Tower Houses-.

Despite this alarming situation, no action is being taken to protect Manor Houses and their characteristic architectural components.
With few exceptions (González, 2004), most current architectural studies focus on facades and exterior elements, leaving aside aspects such as construction systems, structural elements and the interior distribution of these buildings. Consequently, due to a general lack of knowledge about these aspects and the absence of comprehensive protection, many of the current interventions are causing the alteration or complete elimination of elements of heritage value. The problem is greater in some rural areas, where depopulation and a scarcity of economic resources are leading to the progressive abandonment and disappearance of Manor Houses. Many of these have not been catalogued or heritage listed in any form.

This work aims to analyse and characterize the typological evolution of Late Medieval Manor Houses in the Basque Country, so that the results can be used as a guide for future preservation and rehabilitation strategies with respect to this endangered heritage. To this end, several specific objectives were established. These included identifying which historical events motivated architectural evolution; locating, documenting and inventorying the Manor Houses of the Basque Country; developing a "Red List" of buildings in danger of being lost and the locations of those already destroyed; understanding the construction and architectural variables which define the different types of Manor House; and analysing the different functions of these constructions and testing what combinations of uses occurred in different building typologies.

\footnotetext{
* Corresponding author
} 


\section{MATERIALS AND METHODS}

The work was divided into three sections: field work, documentary research and historical-constructive analysis. To facilitate the onsite fieldwork, a data collection sheet was drawn up, which was then expanded and modified over the course of the study (Figure 1). The sheet was organised into five sections: Basic Data, containing information related to the name and location of the building; Current State, in which the heritage listing, accessibility, use and current condition of the building was detailed; Construction, with data on the construction system and architectonic elements; Images, another section with images of the building; and, finally, Observations. In addition, a photographic mapping was undertaken of accessible buildings. Measurements, complete or partial, were taken for a large number of buildings, covering the width, length and height, as well as the thickness of the inner and outer walls.

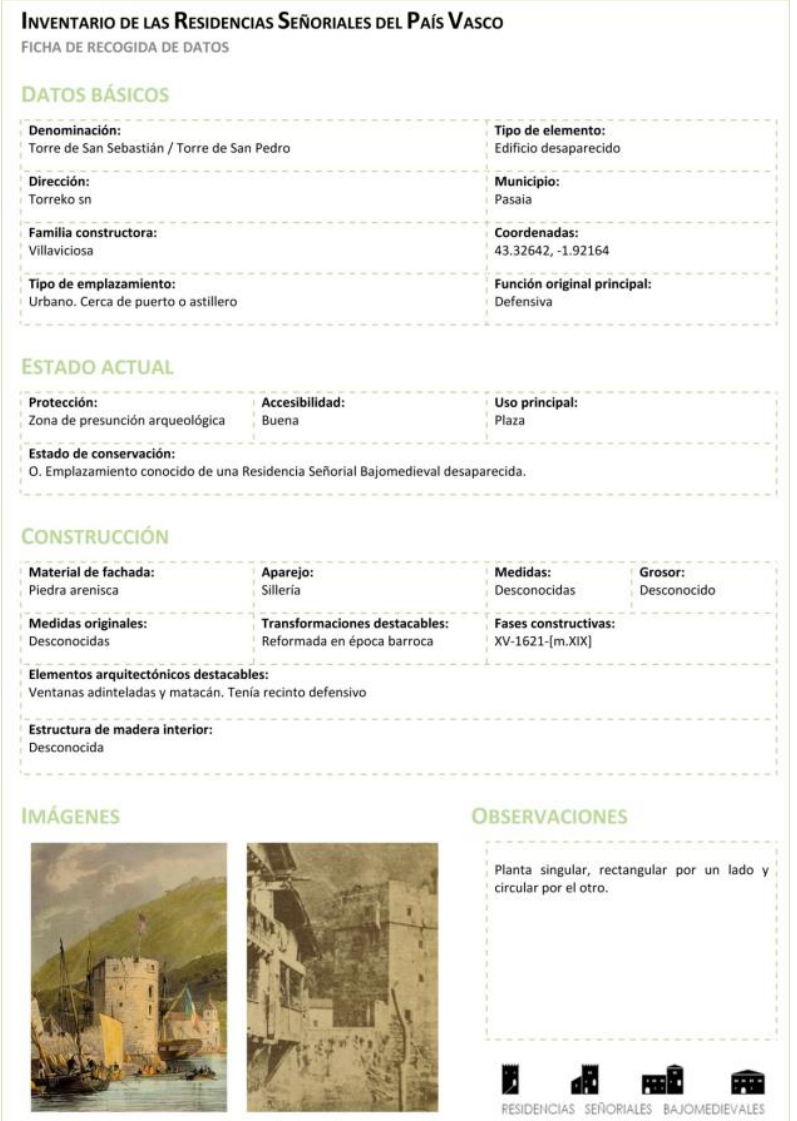

Figure 1. Data collection sheet: Tower of San Pedro (Pasaia).

Most of the historical documents were obtained from the following archives: The General Archive of Simancas, The Archive of the Royal Chancellery of Valladolid, The Basque Historical Archive, The Provincial Historical Archive of Gipuzkoa, The Archive of the Historical Territory of Alava and The Archive of Bizkaia Provincial Council. As to published sources, the work Fuentes Documentales Medievales del País Vasco by Eusko Ikaskuntza (Ayerbe, 2017), and some transcribed medieval chronicles (Aguirre, 1986; Marín Sanchez, 1999; Villacorta, 2015) were particularly useful. Digital databases including Dokuklik, PARES, Virtual Library of Defence, Cartographic Resources of the National Geographic Institute, 19th Century Album, Basque Digital Memory Liburuklik and Meta, were especially helpful and greatly facilitated the research.
The data obtained was uploaded into QGIS software, where the locations of the conserved buildings and also the locations of lost Manor Houses was georeferenced. Maps and background layers were obtained from the GeoEuskadi website. Once data was entered, a transversal comparison was carried out between different buildings. This analysis was done from architectonic, constructive and functional points of view.

\section{TYPOLOGICAL STUDY AND CATALOGUING}

Altogether 2050 constructions were recoded: 675 in Gipuzkoa, 581 in Bizkaia and 794 in Alava. Of the total, 472 correspond with locations of lost Manor Houses, many of which were demolished during second half of the 20th Century. The great destruction of Manor Houses that took place in the narrow valleys of Bizkaia and Gipuzkoa between 1950 and 1970 needs special emphasis. This can principally be attributed to the uncontrolled growth of the cities and the construction of new industrial areas, which demanded large areas of land. In addition, during site visits, it was possible to confirm that at least another 89 Manor Houses are currently in an advanced state of ruin. Failing urgent intervention, these will completely collapse within the near future.

Five typologies of Manor Houses were identified: One defensive, the Tower House, and another four non-defensive, the Tower Palace, Rural Palatial House, Large Palace and Village Manor House. In some cases, the definition of the architectonic type was drawn from models proposed by previous authors (González, 2004; Portilla, 1978). However, these models were necessarily adapted and extended for their application to the heterogeneous existing cases throughout the Basque Country.

In the proposed classification, one of the most relevant parameters is the original function of the building. This conditioned the internal distribution and, therefore, the construction system and external shape. Manor Houses had four types of functions, which were evident to a greater or lesser degree in all buildings: a residential function, a defensive function, a symbolic function and an economic-productive function. The different combinations of these uses were one of the main reasons for which diverse types of Manor House appeared and evolved.

\subsection{Tower Houses}

The oldest type of Late Medieval Manor House identified is the defensive Tower House. As opposed to common wisdom, the first direct references that demonstrate the existence of stately Tower Houses in the Basque Country are very late, from the middle of the 14th Century. According to texts and archaeological remains, during previous centuries the local rural nobility lived in residential complexes composed of small mono-functional buildings, called Palatias, that would not have had defensive structures due to the absence of inter-noble conflicts. There are also documental and archaeological evidences of Rock Castles erected during the 11th and 13th centuries. However, the nobles and their families did not use these defensive structures as their regular or permanent home in this period. In most cases, Rock Castles were used as watchtowers to control the border between the kingdoms of Castile and Navarre.

This situation changed from the mid-14th century. A series of factors - uncontrolled multiplication of lineages, growing power of villages and a severe economic crisis - put at risk the survival of noble families, who suffered an alarming decrease in 
income. In order to maintain their level of rents, many families found themselves forced to increase their territory, causing a series of confrontations between neighbouring clans. These confrontations, within a few decades, developed into a large scale conflict between different factions. Violence extended throughout the Basque Country as part of the so called "War of the Bands".

Motivated by an almost permanent state of war, dominant families began to adopt a much more defensive type of residence, and therefore the construction of Tower Houses proliferated (González, 2004; Luengas-Carreño et al., 2014, 2016; Portilla, 1978). Although there were slight variations, similar buildings can be found in other Northern regions of Spain (AramburuZabala, 2001; Avello, 1991; Cadiñanos, 1987; Caro Baroja, 1982; Cobos, Castro 1998; Cooper, 1991; Ramallo, Alonso 1993) and Europe (Barthélemy, 1988; Contamine, 1988; Cruden, 1960; Emery, 2005; Liebgott, 2009; Macci, Orgera, 1994; Morris, Papadopoulos, 2005; Sherlock, 2011).

To a certain extent, the Tower Houses were a fusion of Rock Castles and Palatias. From Rock Castles, Tower Houses acquired their verticality, military components and external form. These were necessarily adapted to serve as permanent residences for lords and their families. Some of the most important modifications were the increase of the floor area and the size of the facade openings. From Palatias, however, they took residential and productive elements which, up until then, had been dispersed over landholdings. Therefore, it can be said that by means of the Tower House, there was a shift from inhabiting space horizontally to inhabiting space differently, in a vertical and compact manner.

Altogether 223 Tower Houses were inventoried (Figure 2). Most of the constructions have undergone significant modifications. At least 30 Tower Houses were transformed into Palaces during the Late Medieval period. In addition, 140 Tower Houses were totally transformed between the 16th and 21 th centuries. Another 274 sites of now lost Tower Houses were registered. Unlike Rock Castles, normally located on mountain crags, the most common location for Tower Houses was the bottoms of valleys, near commercial routes, from where they would possibly control territory and important strategic points including fords, bridges and natural choke points.

In comparison with other types of Manor Houses, Tower Houses are distinguished by their high defensive capabilities, which often limited their residential and productive functions. They normally had four floors: a ground floor dedicated to storage, a high hall on the first floor, the private chambers on the second floor, and the top floor, which contained most of the defensive elements - battlements, arrowslits, embrasures, turrets, machicolations and hoardings-.

Most of the Tower Houses documented have wide rectangular floor plans, although some square constructions exist. No general pattern between the width and depth of these buildings has been found, although there are similarities between some Tower Houses in geographic proximity. For example, the Tower Houses of Valpuesta (Berberana), Lacorzana (Armiñón) and Mártioda (Vitoria), have a depth of about $9.75 \mathrm{~m}$ (35 latemedieval feet). The Tower Houses of Martiartu (Erandio) and Muñatones (Muskiz) have quite similar dimensions, of approximately $13.65 \mathrm{~m}$ x $15.19 \mathrm{~m}$ ( 49 x 54.5 feet). The buildings with greatest floor area were the Tower Houses of Zamudio $(15.88 \mathrm{~m} \times 16.72 \mathrm{~m})$ and $\operatorname{Orgaz}(17.22 \mathrm{~m} \times 13.37 \mathrm{~m})$, while the smallest Tower Houses inventoried were Barrón $(7.88 \mathrm{~m} \mathrm{x}$ $5.85 \mathrm{~m})$ and Valpuesta $(9.74 \mathrm{~m} \times 6.56 \mathrm{~m})$.
In comparison with other types of Manor House, Tower Houses had very thick walls, normally in excess of 4 late-medieval feet $(1.11 \mathrm{~m})$. The constructions that have thickest walls are Muñatones and Zamudio, both with walls of approximately 10 feet $(2.79 \mathrm{~m})$ thick. As to construction material, the types of stone most used in Tower Houses were limestone (51.4\%) and sandstone $(43.2 \%)$. Most of the existing Tower Houses were erected with irregular masonry (53.5\%), although buildings raised in roughly-hewn ashlars $(16.3 \%)$ or well-hewn ashlars $(25.6 \%)$ also exist.

The internal structure of Tower Houses was normally made using wooden elements in oak. Unlike the constructions of Castile and Galicia, the Tower Houses of the Basque Country did not have stone vaults between floors. The horizontal structure was built with timber beams and joists, which were directly embedded in the walls. This horizontal structure often did not use centre posts, due to the usually shorter distance between the inner faces of the walls.
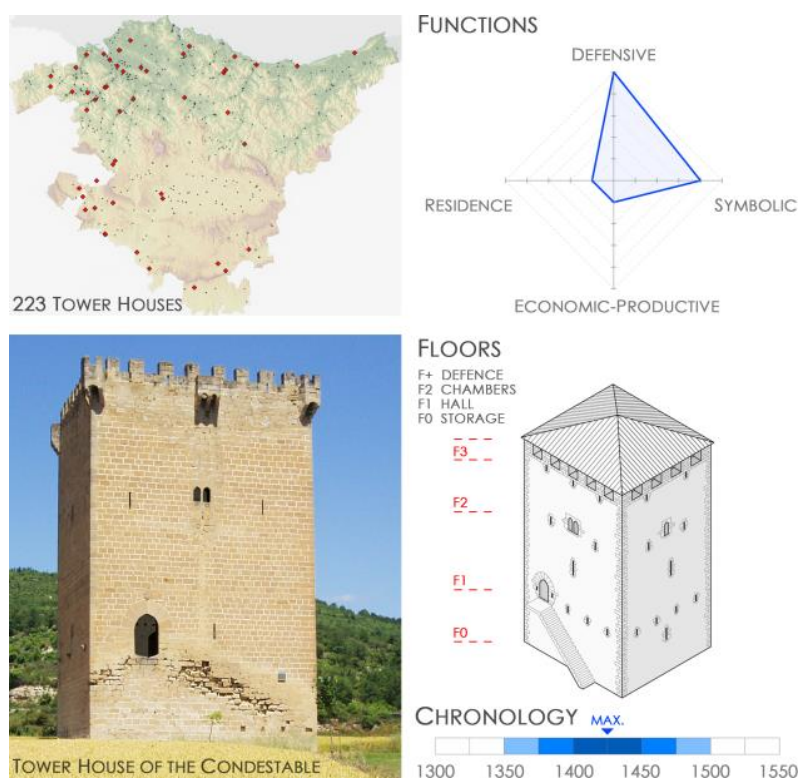

Figure 2. The Tower Houses of the Basque Country.

This type of Manor House had the smallest and least ornamented openings. The largest and most elaborate windows were usually located in the second floor chambers, the most "private" zone of the Tower House. Access to the building was often elevated with respect to the ground level, in order to increase the defensibility of the building (Figure 2).

The worst years of the War of the Bands were from 1420, an era in which a major destruction of Manor Houses in Gipuzkoa, Bizkaia and the North of Alava occurred. Perhaps the most famous events were the attacks that took place in Gipuzkoa between 1456 and 1457, at which time King Enrique IV was forced to intervene in the conflict. Classic authors claimed that in this period a generalised "lopping" of Tower Houses would have occurred: that is, the elimination of the upper part of the buildings. However, neither the documentary sources consulted nor the material sources - surviving buildings of this periodexhibited any evidence of this practice.

With the objective of pacifying the region, from 1457, Enrique IV enacted a policy of anti-band measures which included a prohibition on the construction of new Tower Houses. Nevertheless, everything seems to indicate that, at the outset, 
these measures only had a real effect in Gipuzkoa, which was surely due to presence of a powerful Brotherhood of villages which enforced the law. Consequently, the noble lineages of this province had no option but to begin to adopt unfortified residential models, which gave rise to the appearance of new types of Manor House with a more palatial character.

\subsection{Tower Palaces}

One of the new non-defensive residential types that appeared from the mid-15th century, first in Gipuzkoa and later also in Bizkaia and Alava, were the Tower Palaces. These had more residential and symbolic than seriously defensive functions (Figure 3). Normally, the Tower Palaces were the dwellings of wealthy noblemen, who depended only minimally on agriculture.

The first Tower Palaces tried to emulate the forms and defensive architectonic elements of Tower Houses, with the intention of demonstrating a social status superior to that of the other members of the community. However, unlike Tower Houses, Tower Palaces had very few military elements except for some dissuasive elements such as windows with the shape of arrowslits, corner turrets and machicolated balconies.

Altogether, 255 Tower Palaces were inventoried (Figure 3). Almost half of these buildings $(45.5 \%)$ are located within medieval villages, and many have historically been confused with defensive Tower Houses. In rural areas, most of the Tower Palaces $(35.9 \%)$ are located close to rivers, next to bridges and other productive buildings, such as ironworks, mills and dams.

Unlike Tower Houses, Tower Palaces generally had just two floors and an attic. The ground floor was usually used as a warehouse and stable. The upper floor contained the residential areas, the more public spaces in the front part and the private rooms at the rear, further from the staircase.

In comparison with Tower Houses, in these buildings a slight increase in the floor area is observed. This lead to the use of a greater number of central support posts. Of the cases studied, the buildings with largest floor area are the Tower Palaces of Muntxaraz (16.16m x 17m) and Loyola (16.24m x 16.25m). By contrast, the smallest constructions are the Tower Palaces of La Torre $(8.08 \mathrm{~m} \times 8.36 \mathrm{~m})$ and Barrataguren $(9.11 \mathrm{~m} \times 8.55 \mathrm{~m})$.

In comparison with Tower Houses, Tower Palaces usually had thinner perimeter walls, which were usually less than $0.84 \mathrm{~m}$ (3 late-medieval feet) thick. In these buildings, masonry walls usually had a slight interior staggering, which supported the horizontal wooden structure. As with the earlier architectonic type, the most commonly used materials were limestone (41.5\%) and sandstone (36.8\%). Most of the buildings (78.9\%) were erected using irregular masonry.

Unlike Tower Houses, in Tower Palaces vertical communication between floors was by means of a wooden internal staircase, which started from an ample access vestibule located on the ground floor. Differences with respect to Tower Houses are also observed in the wooden framework. Most of the buildings used one or more intermediate timber posts. These vertical elements were arranged in parallel to the narrowest facades, normally the main and rear. The posts supported transversal beams, which were braced with diagonal elements in some cases. In larger buildings, evidence of dividing loadbearing walls has also been found.
In Tower Palaces, a hierarchical structuring of the facades occurred with greater frequency. Most of the ornamental details were built on the access facade. Similarly, the size and the number of the openings gradually increased, possibly due to the improvement of carpentry and closure elements. In later constructions the use of decorative elements around windows and doors was quite common - stone balls, nails, cordworks, mouldings and other geometric forms-.
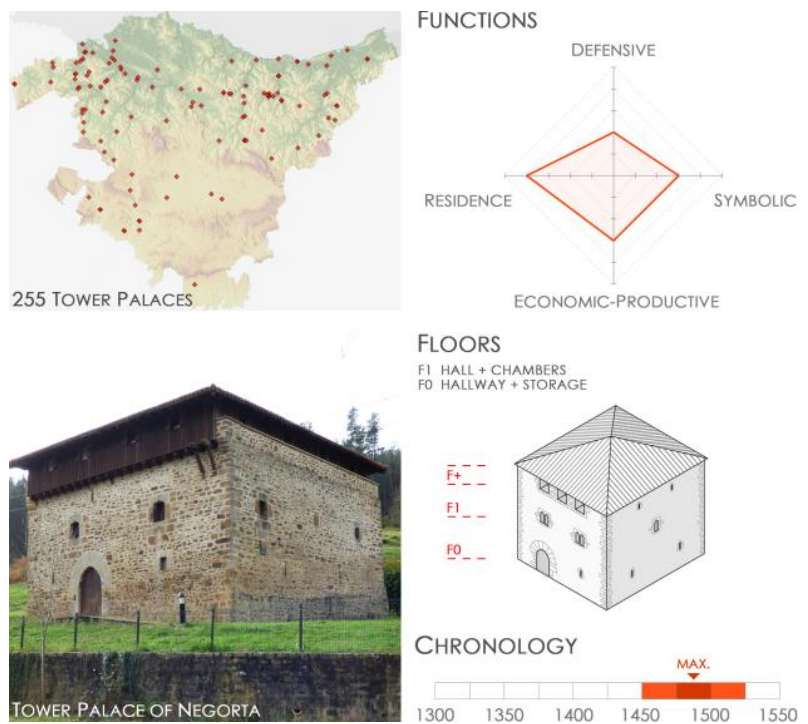

Figure 3. Tower Palaces of the Basque Country.

\subsection{Rural Palatial Houses}

Another type of Manor House that emerged from the mid-15th century was the Rural Palatial House. These buildings were normally the homes of richer small farmers, who did depend on agriculture for their livelihoods. Therefore, in comparison with Tower Palaces, the productive-farming function was much more important in these buildings. For this reason, unlike the previous types, these Manor Houses were most commonly constructed on hillsides, normally in sunny areas close to the limited areas suitable for pasture and cultivation.

Altogether, 118 Rural Palatial Houses were inventoried (Figure 4). They generally included two floors and an attic. The ground floor was totally dedicated to agricultural labour - animal stables and storage of products-. The residential chambers were located on the upper story, the more public spaces at the front and the private rooms at the rear. Both stories were totally separated internally, as access to first floor was by means of an exterior staircase. For this reason, many of these buildings have been traditionally confused with lopped Tower Houses. Each floor of this type of Manor House was generally lower than those of the previous types. This means that these buildings had much more horizontal external facades.

The floor area of Rural Palatial Houses was much greater than that of Tower Palaces, possibly due the need for a larger productive space on the ground floor. The largest examples identified were the Rural Palatial Houses of Zelabear $(20.37 \mathrm{~m} \mathrm{x}$ 20.27m), Etxezabal (20.65m x 19.42m), and Akeuri (20.06m x $19.78 \mathrm{~m})$. Due to their larger floor areas, Rural Palatial Houses generally had more intermediate posts than Tower Houses and Tower Palaces. In quadrangular buildings, the structure was frequently resolved by means of a central framework composed of four or nine central posts, on which the rest of the elements 
were articulated (Luengas-Carreño et al., 2017b). Alternatively, this central support was constructed by means of internal loadbearing walls. In larger buildings, load-bearing walls were combined with rows of timber posts. Rural Palatial Houses generally had less ornamental details than Tower Palaces. As with other types, the largest and most ornate openings were located on the residential floor. In older buildings pointed arch windows were prevalent, whereas in later buildings ogee and lintel openings were more frequent. These were sometimes decorated with balls, nails, flowers and other geometric forms.
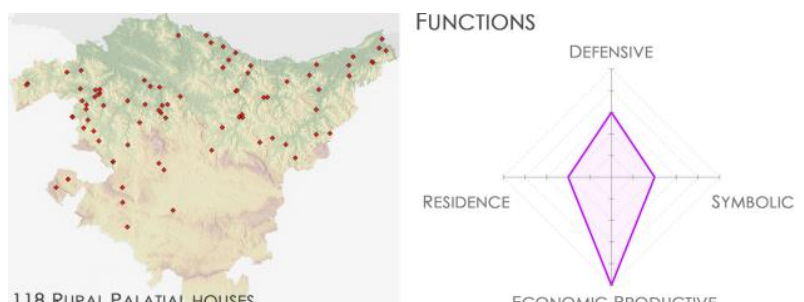

118 RURAL PALATIAL HOUSES ECONOMIC-PRODUCTIVE.

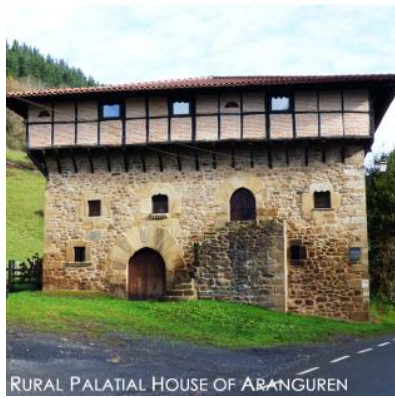
FLOORS FI LUVING SPACES / CHAMBERS

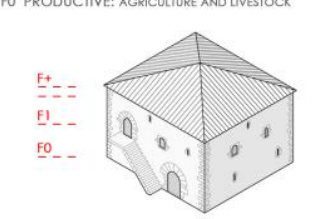

CHRONOLOGY

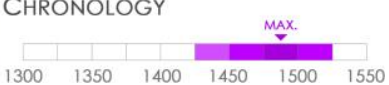

Figure 4. Palatial Rural Houses of the Basque Country.

\subsection{Large Palaces}

In contrast to the Rural Palatial Houses, Large Palaces had primarily residential and symbolic functions. Most of these Manor Houses were built by powerful families or highly placed aristocrats, who were rich enough to erect large and ornate houses. Almost all the buildings inventoried date from the end of 15 th century or, principally, from the early 16th century (Figure 5). Altogether, 140 Large Palaces were inventoried. The majority are located in villages or small rural settlements. In this type of building large floor areas were more common, in some cases in excess of $400 \mathrm{~m}^{2}$. Examples include Elorregi $(23.28 \mathrm{~m} \mathrm{x}$ $21.76 \mathrm{~m})$ and Lili $(22.88 \mathrm{~m} \times 23.3 \mathrm{~m})$.

Like Rural Palatial Houses, these buildings usually had two floors and an attic. However, unlike these, Large Palaces commonly had only one entrance, located on ground floor. From here, an ample vestibule could be accessed, similar to Tower Palaces. Stables were normally on the ground floor, along with storage spaces and servant quarters. On the first floor there was a noticeable improvement in living conditions. New room types such as bedchambers, dining rooms and offices, as well as service elements such as lateral fireplaces and latrines, began to appear.

Unlike the other Manor Houses, a great number of these buildings were constructed in well-hewn ashlar masonry. $71.8 \%$ of the inventoried Large Palaces have at least one of their facings erected completely in ashlar masonry and of these almost half $-34.8 \%$ of the total - have all four facades erected completely in this material. The type of stone most employed is sandstone $(53.8 \%)$. This material was suitable carving blocks and details due to its softness.

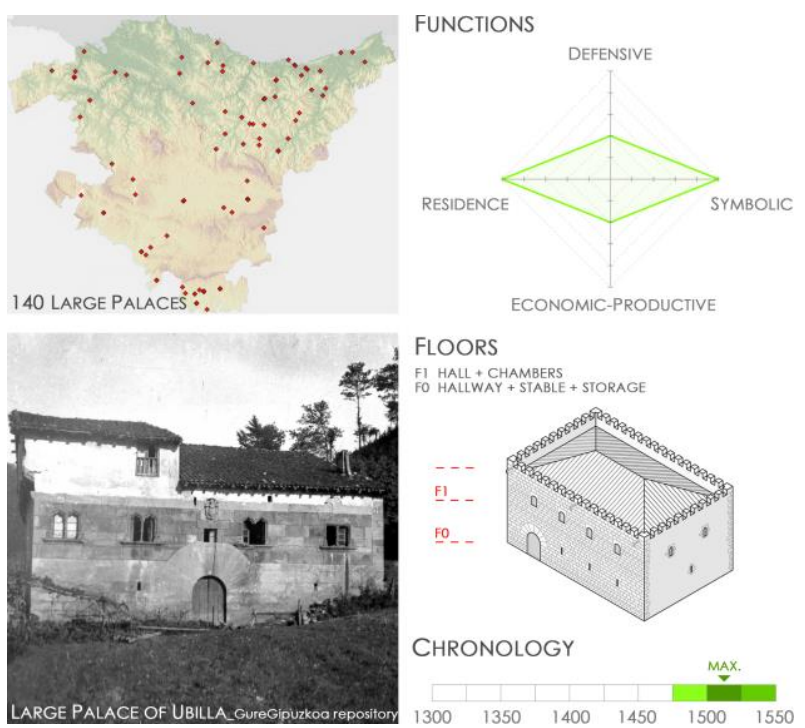

Figure 5. Large Palaces of the Basque Country.

The buildings with larger floor areas had internal load-bearing walls, which divided the interior space in two or three zones. In the smallest buildings, however, rows of timber posts were more common, placed in parallel to the main facade. In both cases, beams were normally supported by lateral braces with horizontal joists and, in some cases, supporting trestles.

As with Rural Palatial Houses, the roofing of the largest buildings was usually constructed using a structural core formed by four or nine central posts. These were braced by means of straps and strut braces in two directions. In some buildings, such as the Guevara Palace in Segura, more complex solutions have been identified. The roof of this Palace is supported by means of king post trusses (LuengasCarreño et al., 2017a).

Large Palaces had openings with the most elaborate designs and decoration. In preserved examples, elements in Catholic Kings style abound - balls, nails, flowers and other geometric forms - . This ornamentation is not only to be found around windows and doors, but also independently. Other types of decorative element can also be identified, including well-hewn coats of arms, frames, crestings and moulded cornices. Some buildings had roofs set back towards the interior, with perimeter guttering in the upper part of the walls. In fact, some elaborately designed gargoyles have also been identified.

\subsection{Village Manor Houses}

The Village Manor Houses were the smallest type of stately residence (Figure 6). These buildings were erected on the narrow lots of late-medieval villages, the shape of which conditioned the distribution of internal rooms. Normally, they were the homes of prosperous citizens including merchants, craftsmen, clergymen, scribes and ship-owners. These elites also used the language of stately architecture to differentiate themselves from the rest of the population.

Although older examples have been identified, most Village Manor Houses were constructed around the end of the $15^{\text {th }}$ and beginning of the 16th century. These residences were closely connected with the professions of their owners. The ground floor was frequently used for shopfronts, offices, warehouses or 
workshops. Above this floor was the noble floor, where the public-private rooms of the residence were located. Finally, the second floor contained the private chambers of the dwelling.

During the research it emerged that the size of a "standard" lot varied significantly from one village to the next. The widths of these constructions varied from $3.34 \mathrm{~m}$ (12 feet), to $10.03 \mathrm{~m}$ (36 feet). As to the depth, buildings have been inventoried that range from $6.68 \mathrm{~m}$ ( 24 feet), to $23.41 \mathrm{~m}$ ( 84 feet). The constructed floor area of these buildings averages $107.6 \mathrm{~m}^{2}$, although several considerably larger examples exist, including the Manor Houses of Antxieta in Azpeitia (10.02m x 17.28m) and Makazaga in Zarautz (10.04m x $16.63 \mathrm{~m})$. By contrast, the smallest buildings inventoried are the Manor Houses of Conception n4 in Moreda de Álava (3.32m x 8.76m) and San Roque $\mathrm{n} 18$ in Labraza (3.34m x 13.28m).

$51.7 \%$ of these buildings were erected completely in sandstone, while $24.5 \%$ were built of limestone. Other Village Manor Houses $(19.7 \%)$ combine stone with timber frameworks and brickwork in the upper floors. The most commonly used stonework is ashlar masonry, which was used in $57.3 \%$ of cases.

The majority of the Village Manor Houses were constructed between two dividing walls, elements that sometimes had internal setbacks to support the horizontal structure. In the narrowest examples — between 12 and 18 feet - beams did not need auxiliary elements of support, such as posts or lateral braces. Beyond 18 feet $(5.01 \mathrm{~m})$ of width, diagonal braces at the ends of the beams were more common. Constructions more than 24 feet $(6.69 \mathrm{~m})$ wide usually had central posts or load-bearing walls. Most of the buildings had gable roofs with eaves. The structure of these roofs was composed of a ridge beam and purlins arranged in parallel to the main facade. In some coastal villages of Gipuzkoa, however, roofs with ridge beams perpendicular to the main facade were more common (LuengasCarreño et al., 2018). In these cases, buildings often had gutters on top of the lateral dividing walls.

With respect to ornamental details, in these buildings decorative elements in Catholic Kings style were quite common, especially around windows and doors. Coats of arms and inscriptions were also common on entrance arcs, which in some cases served to indicate the profession or lineage of the resident family.
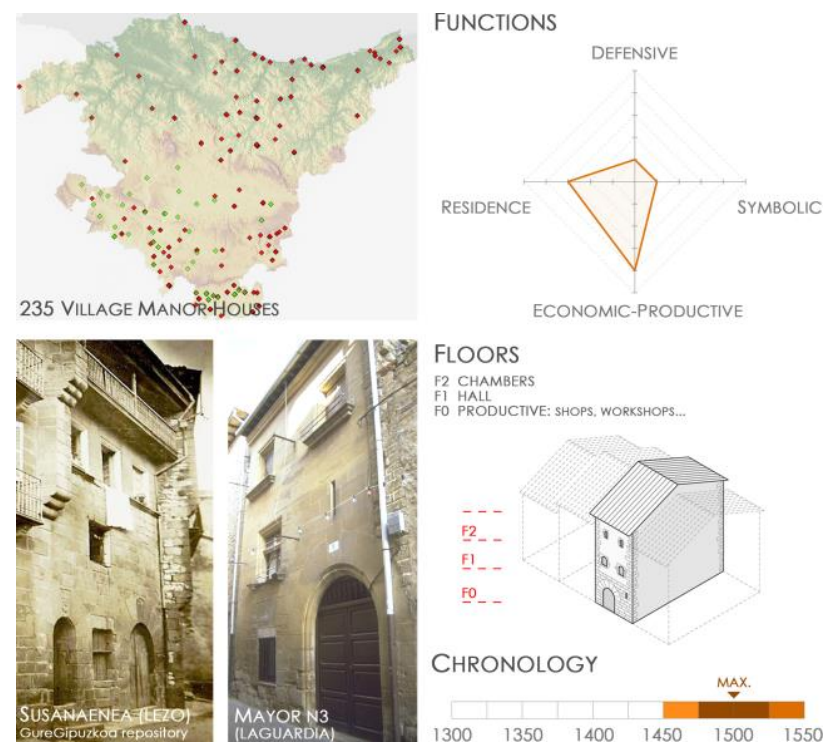

Figure 6. Village Manor Houses of the Basque Country.

\section{CONCLUSIONS}

The typological evolution of Manor Houses in the Basque Country during the Late Middle Ages has been determined. This transformation occurred based on the needs and events of each historical conjecture, which lent itself to an evolution from defensive residential models to others of a more palatial character. In this process five main architectonic types can be identified: one defensive - the Tower House - and other four non-defensives - Tower Palaces, Rural Palatial Houses, Large Palaces and Village Manor Houses-.

Altogether, an inventory of 2050 constructions has been assembled. This document includes information on the constructive periods, geographical coordinates, promoter family, type of location and construction system for each building. The information in this database has been used to compare and to analyse general characteristics of Late Medieval Manor Houses in the Basque Country, as well as to draw up a map of the different types that evolved over time. The information contained in the inventory has been uploaded into QGIS. This information can be exported to the online platforms of different levels of government in the Basque Country.

The inventory also includes the locations of 472 lost buildings. The registered locations will serve to correct errors in current heritage catalogues, as well as to identify new areas of archaeological interest. With a similar objective, a "Red List" has been elaborated. This list identifies buildings in a progressive state of ruin which, without urgent intervention, will completely collapse within the near future.

Contrary to popular belief, only $24.2 \%$ of Manor Houses inventoried were defensive constructions. That is to say, in contrast to the information published in current heritage catalogues, most of the Late Medieval Manor Houses had neither an immemorial origin, nor were they originally defensive Tower Houses.

The construction of palatial models unfolded differently in the three provinces of Basque Country. It occurred earliest in Gipuzkoa from the mid-15th century, and later in Alava and Bizkaia, at the end of that Century. This would explain why a greater number of Tower Houses has been conserved in these two provinces.

In addition, it has been possible to verify a direct relationship between the different types of Manor Houses and the functions that they carried out. Manor Houses had four types of functions which were all present to greater or lesser degree in all construction types: residential, defensive, symbolic and economic-productive.

It has also been observed that a relationship exists between the location type and the architectonic type of buildings. In Bizkaia and Gipuzkoa Tower Houses were usually located at strategically important points in commercial networks and, as far as possible, alongside productive buildings. On the Alava Plain, however, Tower Houses were almost always located on small hills, dominating population centres and their approaches. As to non-defensive buildings, Tower Palaces were normally located alongside productive elements on valley floors, Rural Palatial Houses in sunny hillside zones and Large Palaces and Village Manor Houses in villages or small rural settlements. 
The proposed inventory does not seek to impose a rigid framework, but represents a basis on which to continue working in the future. It will be modified and filled out as different buildings are analysed in greater detail. It is expected that the results of this study can be used as a guide for future preservation and rehabilitation strategies.

On the one hand, the proposed inventory and classification will serve to modify the heritage catalogues currently in force. Nowadays, the erroneous classification of buildings is causing the alteration or partial destruction of Manor Houses -e.g. because non-defensive buildings are confused with lopped Tower Houses-. In addition, the locations of lost Manor Houses will serve to preserve these areas of archaeological interest.

On the other hand, this new knowledge about typologies is being used in a new research project. In collaboration with Prof. Ibon Telleria -Department of Architecture, UPV/EHU—, a cataloguing model for traditional houses of the Basque Country is currently being developed. It is expected also to develop tools to speed up and optimize the previous analysis phase of the architectural interventions data collection sheets, intervention guides, detection of historical elements and pathologies, etc.- .

\section{ACKNOWLEDGEMENTS}

This paper was supported by a research training grant from the Research Vicerrectorate of the University of the Basque Country UPV/EHU. A grant has also been received from the Department of Architecture of the UPV/EHU.

\section{REFERENCES}

Aguirre, S., 1986. Las dos primeras crónicas de Vizcaya. Caja de Ahorros Vizcaína, Bilbao.

Aramburu-Zabala, M. A., 2001. Casonas: Casas, torres y palacios en Cantabria. Fundación Marcelino Botín, Santander.

Avello, J. L., 1991. Las torres señoriales de la baja edad media asturiana. Universidad de León, León.

Ayerbe, M. R., 2017. Fuentes documentales medievales del País Vasco. Eusko Ikaskuntza, Donostia.

Barthélemy, D., 1988. Las instalaciones del espacio privado: Siglos XI-XIII. Historia de la vida privada, vol. 2, 395-420.

Cadiñanos Bardeci, I., 1987. Arquitectura fortificada en la provincia de Burgos. Diputación de Burgos, Burgos.

Caro Baroja, J., 1982. La casa en Navarra. Caja de Ahorros de Navarra, Pamplona.

Cobos Guerra, F., Castro Fernández, J. J. 1998. Castillos y fortalezas: Castilla y león. Edilesa, León.

Contamine, P., 1988. Las instalaciones del espacio privado: Siglos XIV-XV. Historia de la vida privada, vol. 2, 421-502.

Cooper, E. 1991., Castillos señoriales en la corona de castilla. Junta de Castilla y León, Salamanca.
Cruden, S., 1960. The scottish castle. Nelson, Edinburgh.

Emery, A., 1996. Greater medieval houses of England and Wales, 1300-1500. Cambridge University Press, Cambridge.

González Cembellín, J. M., 2004. Torres de las Encartaciones. Diputación Foral de Bizkaia, Bilbao.

Liebgott, N., 2009. The history of small castle in Denmark. Europa Nostra Scientific Bulletin, 63.

Luengas-Carreño, D., Sánchez-Beitia, S., 2014. Las Residencias Señoriales Bajomedievales en el País Vasco: Análisis de la evolución del sistema constructivo y sus elementos singulares. Rehabend 2014, Santander, 110-117.

Luengas-Carreño, D., Crespo de Antonio, M., Sánchez-Beitia, S., 2016. Análisis del sistema constructivo de una Residencia Señorial Bajomedieval defensiva: La Casa-torre de Nograro en Valdegobía (Álava). Segundas Jornadas Sobre Historia, Arquitectura y Construcción Fortificada, Madrid, 423-440.

Luengas-Carreño, D., Crespo de Antonio, M., Sánchez-Beitia, S., 2017a. The evolution of Late Medieval Seigniorial Residences in the Basque Country. Analysis of the Guevara Palace and its constructive system. International Journal of Sustainable Development and Planning, 12(5), 956-967.

Luengas-Carreño, D., Crespo de Antonio, M., Sánchez-Beitia, S., 2017b. La Casa-palacio de Fagoagoa, en Oiartzun (Gipuzkoa): Análisis del sistema constructivo y elementos arquitectónicos originales de una Residencia Señorial Bajomedieval. Actas del X Congreso Nacional y II Congreso Internacional Hispanoamericano de Historia de la Construcción, San Sebastián, 925-934.

Luengas-Carreño, D., Crespo de Antonio, M., Sánchez-Beitia, S., 2018. Donibane n134: Análisis histórico-constructivo de una Casa Señorial de Villa bajomedieval en Pasaia (Gipuzkoa). Rehabend 2018, Cáceres, 47-54.

Macci, L., Orgera, V., 1994. Architettura e civiltà delle torri: Torri e famiglie nella Firenze medievale. Edifir, Firenze.

Marín Sánchez, A. M., 1999. Bienandanzas e fortunas de Lope García de Salazar. Memorabilia: Boletín De Literatura Sapiencial, (3). http://parnaseo.uv.es/Lemir/Textos/ bienandanzas/Menu.htm

Morris, S. P., Papadopoulos, J. K., 2005. Greek towers and slaves: An archaeology of exploitation. American Journal of Archaeology, 109 (2), 155-225.

Portilla Vitoria, M. J., 1978. Torres y casas fuertes en Álava. Caja de Ahorros Municipal, Vitoria-Gasteiz.

Ramallo Asensio, G., Alonso Ruiz, B., 1993. Arquitectura señorial en el norte de España. Universidad de Oviedo, Oviedo.

Sherlock, R., 2011. The evolution of the Irish Tower-house as a domestic space. Proceedings of the Royal Irish Academy, Dublin, 115-140.

Villacorta, C., 2015. Libro de las buenas andanças e fortunas que fizo Lope García de Salazar. Universidad del País Vasco UPV/EHU, Bilbao. 